\title{
Communication Patterns of Sendhang Si Dhukun as a Javanese Symbol to Balance Javanese Ideology and their Social Environment
}

\author{
Zindi Nadya Wulandari*, Prihantoro \\ Department of Linguistics, Faculty of Humanities, Diponegoro University, Semarang - Indonesia
}

\begin{abstract}
The Islamic new year is considered very important for Javanese people, and even the Islamic new year eve, known as Malam Satu Suro, is claimed as a very sacred time. In various areas, Javanese people conduct rituals to welcome this event, such as the one conducted in Sendang Si Dhukun in Parakan subdistrict of Central Java. This paper aims to explain the communication patterns of Sendhang Si Dhukun ritual on Malam Satu Suro ceremony. This research used a descriptive qualitative method. The data used in this research are collected from informants involved in the rituals. The result shows that the ritual cannot be separated from Islamic teaching as it contains a lot of Islamic prayers. In addition, the mixture of Islamic teaching and Javanese culture can be clearly seen in the ritual. The use of Javanese high level (krama) variety and Javanese poetry (kidung) also dominates the communication patterns in the ritual. This indicates that Javanese people adhere to a belief that religion and culture cannot be separated as they can preserve harmonious relation between their ideology and social environment.
\end{abstract}

Keywords: communication patterns, Sendhang Si Dhukun, Javanese culture

\section{Introduction}

Javanese people and traditional ceremonies have a very close relationship. In fact, most Javanese people still hold traditional ceremonies with the aim of preserving culture or nguri-uri kabudayan and preserving the heritage of their ancestors. Javanese people have a variety of traditional ceremonies, one of which is a ceremony to celebrate the Islamic New Year, called Javanese Malam Satu Suro traditional ceremony. Suro or assyura in Arabic means the tenth day of the month of Muharam. Suran is a Javanese new year tradition to commemorate the new year 1 Sura [1]. Beside that, the traditional Suran ceremony is an acculturation of Islamic teaching and Javanese culture. Hence, it is the way to preserve harmonious relation between Javanese ideology and their social environment.

* Corresponding author: zindinadya@gmail.com 
Traji, Parakan Subdistrict, Temanggung Regency, Central Java is one of the region that still preserves Malam Satu Suro traditional ceremony. Malam Satu Suro traditional ceremony is an acculturation of Islam and Javanese tradition. It can be proven by the kidung in the ritual of Sendhang Si Dhukun which contains an expression of gratitude and blessing for the Traji community to the ancestors and The Almighty for all the blessings that have been given.

Research on the Malam Satu Suro traditional ceremony has been conducted by several researchers. Latifah conducted research on the implications of public trust in Malam Satu Suro traditional ceremony toward the aqidah islamiyah of the Traji community. She concluded that the meaning of malam sastu suro in Traji, as long as it does not contradict with Islam, then the tradition of the suron can be implemented and developed [2].

Aswoyo explained that the Suran in Ngisor, Magelang was as a reminder of the Tjipto Boedaya hermitage's existence and as a prayer to The Almighty and they made Malam Satu Suro traditional ceremony as a self-introspection. Some arts must be performed at this Suran ritual ceremony [3].

Then, Prasetiawan wrote the Javanese people's perception of Malam Satu Suro in Margolembo, Mangkutana district, East Luwu. Margolembo community has a perception that Malam Satu Suro is a sacred night which coincides with one Muharram. At malam satu suro, all heirlooms such as keris, stones and other heirlooms are bathed or purified with flowers, the Margolembo community who believe in kejawen, should have a meditation in a sacred place such as a mountain top, a big tree, or sacred cemetery [4].

Siburian \& Malau explained that the purpose of the Suro ritual is to get safety life, avoid the disease, or from distress or we can say it as a tolak bala. They also said that during the ritual process the participant of traditional ceremony were not allowed to say the cursed word because it could disturb the ritual process [5].

Julianti in her study examined Malam Satu Suro which held by the IKJR of Kampar Regency in the village of Suka Mulya SP II. During suroan, IKJR doing various kinds of social activities, such as: blood donation, health therapy, doing gymnastics on Sunday morning and on the peak of suroan they do Kampar bersholawat activities [6].

The problems will be discussed in this research are how is the Traji community respond to the clash between Islam and Javanese traditions at malam satu suro traditional ceremony. Then, what will Traji community do in balancing the Islamic and Javanese traditions in the implementation of Malam Satu Suro traditional ceremony.

\section{Research Method}

This research is a descriptive qualitative research. The data used in this research are collected from informants involved in the rituals.

In order to describe and analyze communication Hymes divide into three units of analysis, there are situations, events, and actions (Hymes in Saville Troike) [7] :

(1) Communicative Situation

The communicative situation is the context in which communication occurs, the situation can remain the same even though the location has changed, or it can change in the same location if different activities take place at different places.

(2) Communicative Event

A communicative event is a basic unit for a descriptive communication goal that includes the same: the same topic, the same participants, the same variety. 
(3) Communicative Act

Communicative act is the part of communicative events. Communicative act generally co-ordinated with a single interaction function, such as referential statement, request, or order and can be verbal or non verbal.

In addition, the researcher also analyzed the language variations in Malam Satu Suro traditional ceremony. Chaer \& Agustina define that variations in language are seen as a result of the social diversity of language speakers and the diversity of language functions. Language variations are divided into several various types, there are variations in terms of speaker, utilization, formality, and facilities [8].

\section{Discussion}

\subsection{Communication Patterns}

The ritual of Sendhang Si Dhukun is the sub event of Malam Satu Suro traditional ceremony. Malam Satu Suro traditional ceremony held in Traji which coincides with the Islamic new year. The ceremony held once a year for three days and become an annual event in Traji. This ceremony is usually held at night. Traji located in Parakan Subdistrict, Temanggung Regency, Central Java. Traji consists of 4 hamlets with 4 RW and 31 RT. The four hamlets are Kauman, Gamblok, Grogol, and Karang Senen.

Malam Satu Suro traditional ceremony involved a number of partisipants consist of Traji villagers, elders, headman and village officials. The participant of the traditional ceremony come from all groups of old, young, and children. Traji community have diversity in their belief; Islam, Christian, and Buddha.

Malam Satu Suro traditional ceremony took places in the village hall, Sendhang Si Dhukun, Kalijogo and Gumuk Guci. Sendhang Si Dhukun is the largest water source in Traji. Besides verbal communication, there are also non-verbal communication in the ritual at Sendhang Si Dhukun. Non-verbal communication in Sendhang Si Dhukun ritual in the form of welcoming the entourage (kirab pengantin) by burning incense by a caretaker, kacar kucur and the disposal of the head and legs of the goat.

The keeper of Sendhang Si Dhukun welcoming the entourage by burning incense after the bridal arrived in the Sendhang Si Dhukun. The burning incense has a purpose of invoking The Almighty so that the ceremony will run perfectly. In addition, burning incense has a purpose as a welcoming ritual for the ancestors in the ceremony. After all the participant of the ceremony and offerings are ready, Kaur Kesra opens the ceremony by reciting the prayer as follows:

A'udzubillahiminasysyaithoonirrojim.Bismillahirrahmaanirrohim. Allohumma sholli wasallim 'ala sayyidina muhammadin sayyidil awwalina wal akhirina wasallim warodliyallohu tabaroka wata'ala an kulli shohabati rosulillahi ajma'in walhamdulillahi robbil 'alamin.

Duh Gusti Allah Ingkang Maha Welas lan Asih,

Sedaya puji syukur namung konjuk wonten ngarsa Paduka Ingkang Maha Agung. Awit sedaya paring dalem kahormatan, kanikmatan tuwin kabagas warasan. Kepareng kawula nyuwun pangapunten saking sakathahing dosa, kalepatan, tuwin kekhilafan. Inggih namung wonten ngarsa Paduka kawula nyuwun pitulungan lan pangayoman. 
Duh Gusti Allah Ingkang Maha Agung,

Kanthi sakathahing keikhlasan, sarta katulusaning manah, kawula warganing Desa Traji mugi tansah pinaringan tetep iman lan taqwa saha katebihna saking tumindak maksiat, nista, hina, lan syirik. Kadidene Paduka anebihaken antawisipun wetan kaliyan kilen.

Duh Gusti Allah Ingkang Maha Wicaksana,

Kawula warganing Desa Traji, wekdal punika nembe ngawontenaken upacara adat, boten sanes namung badhe ngleluri tetilaranipun para leluhur ingkang cikal bakal Desa Traji, mugiya pikantuk karidhaan saking Paduka.

Duh Gusti Ingkang Maha Mirah,

Kawula warganing Desa Traji, punapa dene sedaya ingkang kempal ing papan punika manuwun dhumateng ngarsa Paduka mugiya sedaya warganing Desa Traji tansah pinaringan kawidadaan, karaharjan, lir ing sambikala, tebihna saking rubeda, kadumugi ingkang sineja. Para among kisma mugiya tansah nemahi tukul ingkang sarwa tinandur. Tuwuh kang sarwa tinancepake. Para among dedagangan tansah pinaringan kasil ingkang kathah lan berkah, para ingkang ngasta wonten ing babagan pemerintahan minggahing para among praja punapa dene para manggalaning praja mugiya tansah saged numandhukaken jejibahanipun.

Duh Gusti Allah Ingkang Maha Linangkung,

Mugiya wonten kepareng dalem, para manggalaning praja, para satriyaning nagari, para pangarsaning bangsa, miwah para ulama "lan umara" tansah pinaringan kakiyatan lahir batos, tetep iman lan ikhlas. Kanthi sae anggenipun mranata bangsa lan negari ngantos dados kadumugen gagayuhaning masyarakat adil makmur reja rejeh, tentrem ayem.

The prayer began with the thanks giving to The Almighty for the health and safety given to the Traji community. In this prayer they ask an apology for all the sins they have made. They also ask for protection and help from The Almighty. They also ask The Almighty for Malam Satu Suro traditional ceremony -which was a heritage from the ancestors- to get His blessing.

They hope that farmers can get what they have plant in the farm. The traders have a lot of income and blessings, hopefully the government can carry out their duties properly. They also beg that the government and ulama are given the physical and spiritual strength, strong faith and sincerity; so they can lead the country in a right way in order to get prosperous and peaceful society.

Every religion has the same position. The Traji community which consists of various religions must be united and they should have a high tolerance. Therefore, to maintain the diversity between them, it was agreed that the recitation of kidung or prayers in Javanese would be carried out in the Sendhang Si Dhukun ritual. Bellow are kidung that are sung at the ritual at Sendhang Si Dhukun:

\author{
I. Sun angidhung sinekar hartati \\ Amengeti tanggap warsa enggal \\ Satunggal Suro Wulane \\ Sagung warga nyengkuyung \\ Datan ana kari sawiji \\ Sayek saeka praya \\ Mrih tantah lestantun \\ Nguri-uri Kabudayan \\ Jawa asli kang den anut yayah wibi
}

sing the kidung

to celebrate the new year

Satu Suro

all the citizen attend

no one left behind

all the community help each other

for always preserving

preserving the culture

(Javanese culture) which

adhered by the anchestor 
Sesaji maring sendhang

II. Jroning batos tansah amemuji

Kamirahanipun Kang Maha Kwasa

Kang wus paring tuk kang gedhe

Aran Sendhang Si Dhukun

Toyanipun amurakabi

Kali lan sawah

Kiwa tengenipun

Sinangga ing pembangunan

Dham bendhungan kabetahaning para tani

Temah dadiya warata

III. Wulan Suro tumrap warga Traji

Dadiya panjer ing karukunan

Sarwi tansah gotong royong

Dyan len agaminipun

Datan mawas sugih lan miskin

Samya cancut tumandang

Bangun dusunipun

Pasrah sumarah manembah

Marang Allah Gusti sagunging dumadi

Asas kang pancasila

IV. Miwah nggelar kabudayan Jawi

Ringgit purwa miwah karawitan

Tan kari jaran kepange

Wah tirakatan nutup

Ing pangajab Gusti berkahi

Paring kawilujengan

Tulus kang tinandur

Cekap sandhang kaliyan boga

Adil makmur ayem tentrem kang den esti Widada salaminya give the ritual offering to sendhang

in their heart always praise

to the God's grace

which has given a large spring

called Sendhang Si Dhukun

the water is sufficient

the river and the rice fields

on the left and the right side

with the construction

dam as the needs for the farmers

so the water can be distributed

for Traji people, Suro

mean as creating a harmony

with mutual cooperation

despite different religions

not looking at rich and poor

all always participate

to build a village

always surrender

to the God who becomes

the principle of Pancasila

in organizing the Javanese culture

with shadow puppets

or kuda lumping

with tirakatan

addressed to the God Almighty

the safety giver

over all plants

in order to fulfill the needs of clothes and food

just, prosperous, and the expected peace

happines, forever

The meaning of the kidung are:

First stanza explained that the villagers of Traji began the ritual at Sendhang Si Dhukun by singing the kidung in every Malam Satu Suro celebration. In this traditional ceremony, they work together to preserve the ancestor's heritage. They also give ritual offering to Sendhang Si Dhukun as an expression of their respect for the ancestors.

Syncretism or a mixture of two or more elements occurs because people adopt a new belief and try not to clash with old cultural ideas and practices [9]. It is represented by giving ritual offering in Sendhang Si Dhukun; acculturation between the animism, Islamic and Hindu traditions. Some of the ritual offerings in the Sendhang Si Dhukun ritual are from the agricultural products of the Traji community which consist of rice plant, vegetables, fruits and tubers.

Ritual offering which contain agricultural products show that the Traji community work as a farmer. That ritual offering is a form of gratitude from them to their ancestors for the abundant springs in the form of Sendhang Si Dhukun. 
Sendhang Si Dhukun is a sacred place for the Traji community. They believe that Sendhang Si Dhukun brings many benefit or fortune for them. It can be said that the ritual offering has a function to consecrate the spring in order to keep the preservation of Sendhang Si Dhukun and to protect it from the exploration.

The purpose of second stanza is praising for what God gave to the Traji community in the form of large spring called Sendhang Si Dhukun. Sendhang Si Dhukun has many blessings and benefits for them, they can use the water for their daily need and irrigating the rice fields they have.

In ancient times, the spring in Sendhang Si Dhukun was in the form of river and it was only irrigating the rice fields which located under the river. Then the community built a dam in order to make the water can be evenly distributed in irrigating their field. In addition, they also believe that they can use the water as a medicine, because it contains a low e-coli bacteria.

The third stanza shows that Malam Satu Suro traditional ceremony has a meaning to make a harmonious relation with others. Even they have different backgrounds, people in Traji always help one another to develop the village.

The last stanza in the kidung shows that all the rituals are for The Almighty; the giver of salvation. Traji community hope that their need can be fulfilled.

Based on the level speech of language, there are a number of sentences or vocabulary written using Krama Javanese and in terms of language use, the kidung is written using Javanese kawi. Kidung at the Sendhang Si Dhukun ritual is performed by Mas Triyono, one of the event organizer in Malam Satu Suro traditional ceremony.

During the kidung is sung, there is a non-verbal communication called kacar kucur ritual performed by the couple's bride, Pak Lurah and Bu Lurah. In the kacar kucur ritual, the bridegroom or Pak Lurah will spill all the contents of the cloth containing rice to the cloth brought by Bu Lurah. Kacar kucur is a symbol where the Lurah is distributing fortune to the community. Then the event continued with the dumping of goat head and legs into a pond near the ceremony site. The goat head and legs are believed by Traji residents as ritual offering to Sendhang Si Dhukun.

According to Moertjipto, slaughtering goats for offering, besides as a blessing, giving goat as an offerings is the ceremony's completeness [10]. The head of the goat has its own meaning in Malam Satu Suro traditional ceremony, that is as a sacrifice so that the Traji people are always protected by the Almighty. In addition, the head of the goat is a symbol of Traji's people gratitude for Sendhang Si Dhukun which has many benefits.

The dumping of goat head and legs welcomed by the children who scrambled to get it by swimming in the pool. In this ritual, the head and legs of the goat must enter the Sendhang Si Dhukun before the children catch them. The next ritual is the closing prayer by Kaur Kesra.

"Baldatun toyyibatun warobbun ghofur. Yasirlana kullal umuri wa'afiina min kulli hammin au bala au'ani. Allohumma sallimna wasallim dinana wasallim imanana wasallim ma'rifatana wasallim jama'atina min afatiddunya wa'adzabil akhiroh. Robbana atina fiddunya hasanah wafil akhirotihasanataw wa-qina adzabannaar washolallohu'ala sayyidina muhammadin subhana robbika robbika robbil 'izzati amma yashifun wasalamun'alal mursalin wal hamdulillahi robbil'alamiin."

The prayer represents the community's hope for being kept away from calamities and disasters and ask The Almighty to protect them from doom in the afterlife. After reading the prayers, the event continued with the distribution of offerings to the attendance of malam satu suro traditional ceremony.

Satu suro occured because of the myths and stories of the ancestors. Previously, in the era of animism and dynamism in the transition from Mataram Kuno, there had to be ritual offering for every spring in the form of human. Then, in the era of Islamic Mataram the 
human offerings was replaced by a goat. The process of slaughtering goat for worship in this ritual is guided by the Islamic law.

As we know, Malam Satu Suro traditional ceremony is an acculturation of Islam and Javanese traditions. The clash between Islam and Javanese traditions in the Sendhang Si Dhukun ritual at Malam Satu Suro traditional ceremony is still found by the existence of a ritual such as laying ritual offering or other alms. Nowadays, Traji community try to understand and comprehend this conflict by considering that the ritual at Sendhang Si Dhukun is a kind of culture that must be preserved. Because of this traditional ceremony, Temanggung government make Traji as a cultural tourism village. The government also dubbed Traji as a mini Indonesia.

Besides Islam, Traji has a community with a variety of religions such as Islam, Christian and Buddha. Previously, Malam Satu Suro tradition had become a problem, because it against the religious teaching. However, now the government and the Traji community have a solution to balance the religious teachings and Javanese traditions. They changed their mind and had a view that Malam Satu Suro tradition was a gathering event for all religious communities.

\subsection{Language variations in rituals at Sendhang Si Dhukun}

\subsubsection{Language variation in terms of formality}

The language variety used in the ritual at Sendhang Si Dhukun is a frozen language style. Frozen language style is the most formal language variation, it is usually used in formal ceremony. Here is the example of frozen variety in Sendhang Si Dhukun ritual :

"Sumonggo kita persani sesarengan lumaksananing upacara wonten ing Sendhang Si Dhukun wekdal menika. Para pamirsa kadang sutresno sak purnaning lumaksana upacara adat ing Sendhang Si Dhukun uba rampe upacara ingkang kanthi hasil bumi warga masyarat Traji punika dipun rebat dening para kadang ingkang rawuh wonten papan mriki wonten satunggaling kawigatosan bilih waget pikantuk uba rampe hasil bumi menika lajeng dipun simpen dibeto kondur."

The speech has a meaning or suach a request for the participants of malam satu suro traditional ceremony who received the ritual offering to bring it at home.

\subsubsection{Language variation in terms of speaker}

Language variation in terms of speaker means that they are determined by the speakers of the language, social position, gender, and time of language used.

Javanese language has level of speech. Based on the level of politeness, Javanese devided into ngoko, madya, and krama. Krama has the highest position of politeness in Javanese. The master of ceremony used Krama in this ritual. Krama is used to show respect for speech partners who have higher position than the speaker [11]. Krama is used by people as a sign of respect for the person spoken to. In addition, Krama is also commonly used in official events, one of which is Malam Satu Suro traditional ceremony. Below is an example of a speech from the master of ceremony:

"Para kadang tresno ingkang kinasih, panjenengan tasih mresani dokumentasi pengetan tanggal setunggal suro desa Traji kecamatan Parakan kabupaten Temanggung. Rombongan utawi arak-arakan ingkang badhe tumuju wonten Sendhang Si Dhukun sampun jengkar saking Balai desa Traji tumuju wonten ing jalan raya kawit dening para kadang linmas minangka keamanan ingkang pun biyantu dening sederek saking Polsek Parakan dalah Polres Temanggung kaderekaken para panayu saha para dhomas wonten 
ing umparaping upacara ingkang kasto wekdal punika wujudaken hasil bumi warga masyarakat Traji."

In the speech, the master of ceremony in Malam Satu Suro traditional ceremony gave information to the participants of the ceremony that the procession would go to Sendhang Si Dhukun. Security guard (linmas) in Malam Satu Suro traditional ceremony was assisted by the Parakan Police and Temanggung Police to maintain the safety of the event.

\subsubsection{Language variations in terms of utilization}

Language variations in terms of utilization appear in the use of register. Register is a variety of certain languages that are used for certain purposes, as feedback from social or regional dialects [12]. Register is the language variation based on their domain. In other words, the register is a variation of the language used based on the field of use, style, or level of formality, and the means of use.

The recitation of prayer in Sendhang Si Dhukun ritual uses two languages, there are Arabic and Javanese. After Pak Kaur Kesra recited prayers in Arabic, he continued to recite prayers in Krama Javanese. This is because this event is a Javanese traditional ceremony and the Traji community are begging or communicating to their ancestors by praying that they are always given help and protection. The following is a fragment of prayer at the ritual at Sendhang Si Dhukun:

"A'udzubillahiminasysyaithoonirrojim. Bismillahirrahmaanirrohim. Allohumma sholli wasallim 'ala sayyidina muhammadin sayyidil awwalina wal akhirina wasallim warodliyallohu tabaroka wata'ala an kulli shohabati rosulillahi ajma'in walhamdulillahi robbil 'alamin. Duh Gusti Allah Ingkang Maha Welas lan Asih, Sedaya puji syukur namung konjuk wonten ngarsa Paduka Ingkang Maha Agung. Awit sedaya paring dalem kahormatan, kanikmatan tuwin kabagas warasan. Kepareng kawula nyuwun pangapunten saking sakathahing dosa, kalepatan, tuwin kekhilafan. Inggih namung wonten ngarsa Paduka kawula nyuwun pitulungan lan pangayoman."

The prayer means that Traji community apologize for all the mistakes and ask the Almighty and the ancestors to give them the safe and peace life.

\subsubsection{Language variation in terms of facilities}

Language variation in terms of facilities are seen in terms of the mean used. In this terms, there are spoken and written style. The variation in terms of facility which can be found in the ritual at Sendhang Si Dhukun is spoken style. In this spoken style, it is assisted by nonsegmental elements or non-linguistic elements in the form of non-verbal actions such as the ritual of kacar kucur and incense burning.

\section{Conclusion}

From the description above, it can be concluded that Malam Satu Suro traditional ceremony held in Traji which coincides with the Islamic New Year. The ceremony is always held once a year for three days and it is usually held at night. The places used in Malam Satu Suro traditional ceremony are the village hall, Sendhang Si Dhukun, Kalijaga, and Gumuk Guci. The participants in Malam Satu Suro traditional ceremony consist of Traji community, elders, the keeper of Sendhang Si Dhukun, headman and village officials. In the ritual at Sendhang Si Dhukun, there are several non-verbal communicative actions; burning incense, kacar kucur and dumping of goat head and legs. 
There are a number of language variations used in this ceremony, there are language variation in terms of formality, language variation in terms of speaker, language variation in terms of utilization and language variation in terms of facility. In the language variation in terms of formality, the variety of languages used in the Sendhang Si Dhukun ritual is a frozen language style. Where the frozen style is the most formal language variation and it is commonly used in formal ceremony. Language variation in terms of speaker means that they are determined by the speakers of the language, social position, gender, and time of language used. In carrying out this ritual, the master of ceremony used the Krama Javanese. The next language variation is the language variation in terms of utilization. The language variation in terms of utilization concerns the language used for a purpose. For example, when reciting prayers in the ritual at Sendhang Si Dhukun used two languages; Arabic and Javanese. In terms of facility, language variations are divided into two, there are spoken and written style. Ritual at Sendhang Si Dhukun only use spoken style only.

\section{References}

1. Kamajaya, Satu Sura Tahun Baru Jawa Perpaduan Jawa Islam, 6 (1992)

2. A. Latifah, Kepercayaan Masyarakat terhadap Upacara Tradisi Satu Suro di Desa Traji Kecamatan Parakan Kabupaten Temanggung (2014)

3. J. Aswoyo, J.P.S.B, 6 (2014)

4. I. Prasetiawan, Persepsi Masyarakat Jawa terhadap Budaya Malam Satu Suro (2016)

5. A.L.M. Siburian, W.Malau, J.S.D.B, 2 (2018)

6. T. Julianti, J.O.M.F, 5 (2018)

7. S.M. Troike, The Ethnography of Communication: An Introdution (Third Edition), 23 (2003)

8. A. Chaer, A.Leoni, Sosiolinguistik: Perkenalan Awal, 81 (1995)

9. Sutiyono, J.P.H, 16, 58 (2011)

10. Moertjipto, et al. Wujud, Arti dan Fungsi Puncak-Puncak Kebudayaan Lama dan Asli Bagi Masyarakat Pendukungnya di Daerah Istimewa Yogyakarta, 92 (1996/ 1997)

11. E. Susylowati, Kesantunan Berbahasa Jawa dalam Kraton Hadiningrat, 10 (2006)

12. A.C. Alwasilah, Pengantar Sosiologi Bahasa, 63 (2012) 